\title{
PRELIMINARY REPORT ON THE NEW FINDINGS OF MISSISSIPPIAN TRILOBITES IN THE BŘEZINA FORMATION (MORAVIAN KARST, CZECH REPUBLIC)
}

\author{
Tomáš Weiner', Carsten Brauckmann², Hedvika Poukarová', Štěpán Rak³, Jiří Kalvoda' \\ ${ }^{1}$ Masaryk University, Department of Geological Sciences, Kotlářská 2, 61137 Brno, Czech Republic; e-mail: tomasweiner@volny.cz \\ ${ }^{2}$ Clausthal University of Technology, Geology and Palaeontology, Leibnizstrasse 10, D-38678 Clausthal-Zellerfeld, Germany \\ ${ }^{3}$ Charles University, Institute of Geology and Palaeontology, Albertov 6, 12843 Praha 2, Czech Republic
}

(24-41 Vyškov)

Key words: Moravian Karst, Březina Formation, Mississippian, Viséan, trilobites

\section{Abstract}

New fossiliferous layers of the Březina Formation were discovered in the valley of the Řička Brook SSW of the village of Ochoz u Brna in 2011. Four taxa of trilobites were preliminary determined: Archegonus (Phillibole) $c f$. polleni (Woodward, 1894), Archegonus (Phillibole) $c f$. cauliquercus Brauckmann 1981, Liobole (Liobole) glabra proxima Chlupáč, 1966 and ?Spinibole sp. The newly dis-

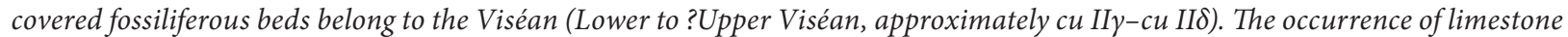
pebbles and limestone cobbles in aleuropelitic shales was also recorded. The Late Tournaisian foraminifer Darjella monilis Malakhova, 1964 was discovered in a dark grey limestone cobble derived from the Hády-Řička limestone sequence of the Lišeň Formation.

\section{Introduction}

Trilobites from the Brezina Formation were previously reported from several localities: Zbrašov near Hranice (Chlupáč 1956, Chlupáč 1958), Březina (Chlupáč 1966, Rak - Viktorýn 2010), the valley of the Ríćcka Brook (Chlupáč 1966), Čelechovice (Chlupáč 1969) and the Mokrá quarry (Chlupáč 1966, Rak 2004, Rak - LeroseyAubril 2009, Kalvoda et al. 2010 , Rak et al. 2012).
New trilobite-bearing beds of the Březina Formation were discovered in the valley of the Rićcka Brook near Brno in 2011. The new material was collected from an outcrop situated on the right bank of the Ríčka Brook, approximately $150 \mathrm{~m}$ NWW from the „Koupaliště“ (= "bathing place“) hiking signpost, approximately $2.5 \mathrm{~km} \mathrm{SSW}$ of the village of Ochoz u Brna (fig. 1). Aleuropelitic shales exposed therein are prevalently greenish, considerably

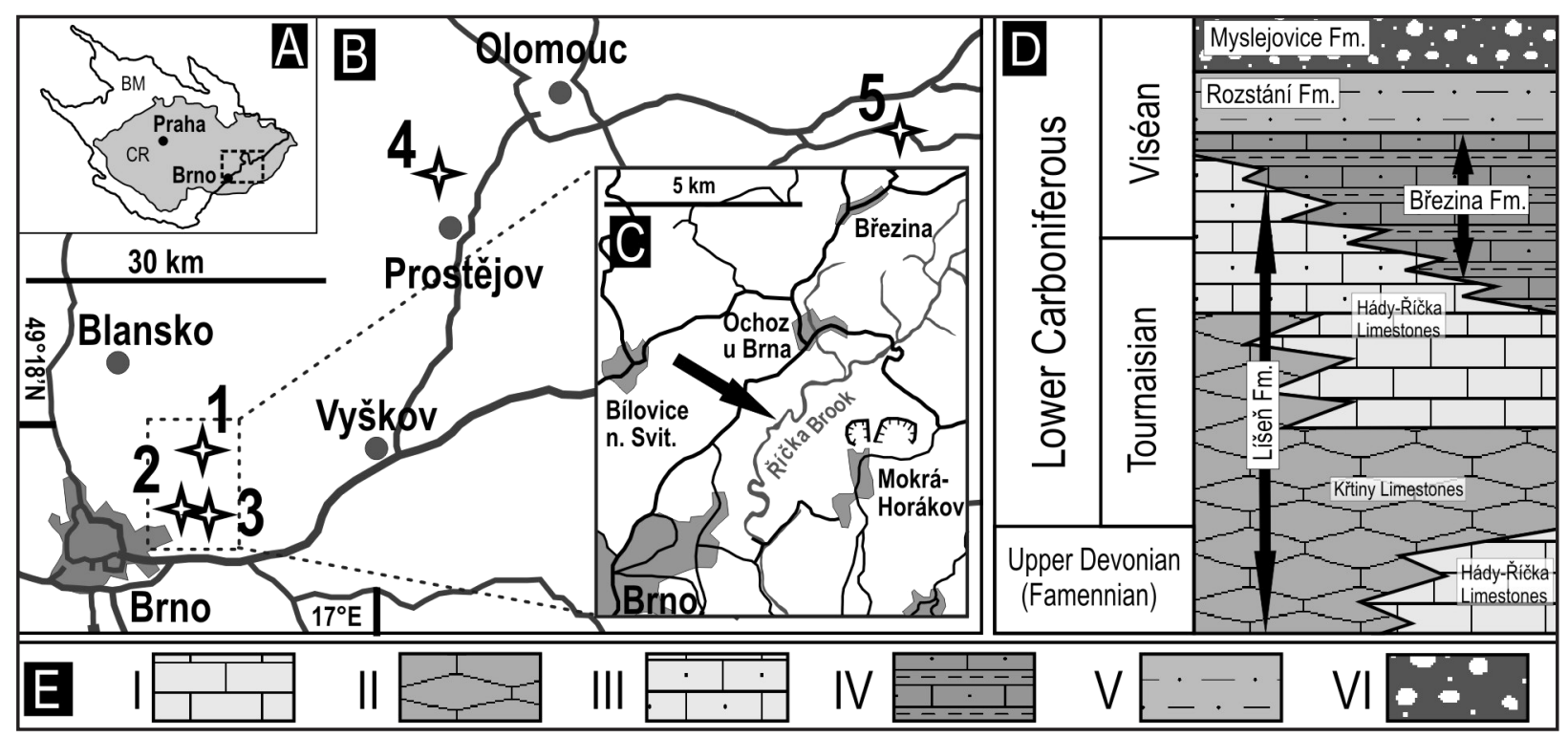

Fig. 1: A - Location of all known trilobite occurences of the Březina Formation in the southeast part of the Czech Republic (CR) and the Bohemian massif (BM). B - Localities of the Březina Formation with trilobite occurence: 1 - Březina, 2 - valley of the Ríčka Brook, 3 - Mokrá quarry, 4 - Čelechovice, 5 - Zbrašov near Hranice. C - Geographic position of the new locality (marked by arrow) in the south part of the Moravian Karst. D - Schematic stratigraphical column of the Late Devonian and Early Carboniferous of the Moravian Karst; modified after Kalvoda et al. (2010). E - Lithological symbols used in the stratigraphical column: I - limestones (commonly cherty) with thin intercalations of shales (Líšeň Fm.), II - limestones, commonly nodular (Líšeň Fm.), III - limestones (commonly cherty) with thin intercalations of shales; sandy limestones (Lišeň Fm.), IV - aleuropelitic shales and limestones (Březina Fm.), V - aleuropelitic shales (Rozstání Fm.), VI - conglomerates, greywackes, shales (Myslejovice Fm.). 
silicified and poorly bedded. Trilobites, associated with brachiopods, bivalves, cephalopods, corals and crinoids, were obtained from an interval of approximately $0.5 \mathrm{~m}$ thickness. Several limestone pebbles and a limestone cobble were also found within these shales. More then 80 remnants of trilobites including about 20 almost complete specimens and about 60 isolated parts of exoskeletons were collected. Tectonic deformation complicates their determination. Several specimens from this locality were now preliminary studied and deposited in the palaeontological collections of the Czech Geological Survey, Prague (inventory numbers TW1-TW4).

\section{Systematic Part}

Class Trilobita Walch, 1771

Order Proetida Fortey - Owens, 1975

Family Phillipsiidae Oehlert, 1886

Subfamily Archegoninae Hahn - Brauckmann, 1984

Genus Archegonus Burmeister, 1843

Subgenus Archegonus (Phillibole) Richter - Richter, 1937

\section{Archegonus (Phillibole) cf. polleni (Woodward, 1894)}

Remarks: The morphology of the complete specimen (TW1, fig. 2A) is close to Archegonus (Phillibole) polleni chiefly due to the short genal spine reaching approximately the first thoracic segment and by the size of the eyes. Although the eyes were broken off, the shape of the fracture line suggests that they were large. As judged from poorly preserved material, the pygidial border seems to be very indistinct or rather absent in comparison with the lectotype of A. (Ph.) polleni depicted by Woodward (1894) and Prentice (1967).

A. (Ph.) polleni occurs in Great Britain, Germany and very probably also in Ireland (see Archinal 1992, p. 21). In Germany (Rhenish Massif: Bergisches Land) A. (Ph.) polleni appears in two completely different horizons (cu II? $\gamma$ $=$ ?Late Chadian and cu III $\alpha$ = Asbian; Brauckmann 1992, p. 126); both materials cannot yet be distinguished by the preserved characters. In Northern England (type region) the true $A$. (Ph.) polleni is restricted to the latter sequence. The species seems to cover a complete time interval from the Late Chadian to the Asbian (cu II? $\gamma$-cu IIIa, Lower to Upper Viséan).

Archegonus (Phillibole) cf. cauliquercus Brauckmann, 1981

Remarks: Two almost complete specimens (TW2, fig. $2 \mathrm{~B}, \mathrm{C}, \mathrm{E})$, probably belonging to the same species, are preserved together in one piece of rock. In the first specimen (fig. 2C, E) the right genal spine was completely broken off. The mould of the fragmentary left genal spine suggests its long and tubular shape (fig. 2E). In the second, a markedly disarticulated specimen (fig. 2B), the right librigena is completely lacking, but the left librigena reveals a long tubular genal spine. In both specimens the eyes are not preserved. Due to the considerably poor preservation, the course of the facial sutures can be only locally distinguished. As far as observable, the palpebral lobes seem to be rather large, which suggests the rather large size of the eyes (typical for Archegonus (Phillibole) aprathensis subgroup sensu Müller
- Brauckmann 2010). Both specimens are very similar to Archegonus (Phillibole) cauliquercus which was previously known from the cu IIIa 2 sequence (Asbian, Upper Viséan) in Germany (Bergisches Land; see Archinal 1992; p. 11).

\section{Genus Liobole Richer - Richter, 1949}

Subspecies Liobole (Liobole) Richter - Richter, 1949

\section{Liobole (Liobole) glabra proxima Chlupáč, 1966}

Remarks: The cranidium (TW 3) depicted in fig. 2G is markedly deformed. The course of the facial sutures as well as the shape of the glabella make it possible to determine this specimen as Liobole (L.) glabra proxima due to the following characteristics: posterior fixigenae extremely broad, $\zeta$ not marked, and constriction of glabella between $\gamma$ and $\gamma$ lacking.

This subspecies was originally described in the Czech Republic (Viséan, cu II $\gamma$; localities Březina, Čelechovice "horizon with Spinibole olgae") by Chlupáč $(1966,1969)$. Subsequently Owens - Tilsley (1995) reported Liobole (L.) glabra proxima in south-west England (North Devon; Lower Viséan: Late Chadian, cu II $\gamma$ ).

\section{Subfamily ?Cystispininae Hahn - Hahn, 1982 \\ ?Spinibole sp. Chlupáč, 1966}

Remarks: The thoracopygon (fig. $2 \mathrm{~F}$ ) is similar to three species, i.e. Spinibole (Spinibole) ruethenensis Hahn - Hahn, 1969 (= Wagnerispina ruethenensis, sensu Gandl 1977 and Owens - Tilsley 1995), Spinibole (Combewoodia) coddonensis (Woodward, 1902) (= Wagnerispina coddonensis, sensu Owens - Tilsley 1995) and Wagnerispina wagneri Gandl, 1977. The slightly subtriangular shape of the pygidium is closer to Spinibole (Sp.) ruethenensis. Although the assignment to the genus Spinibole is probable, this specimen cannot be unequivocally allocated to a particular species because of the lack of the cephalon. Stratigraphic range and distribution of similar taxa: Spinibole (Sp.) ruethenensis is known from Germany (Asbian, cu II $\delta$, Upper Viséan; Rhenish Massif, Harz Mountains). Specimens similar to Spinibole (Sp.) ruethenensis were currently recorded by Rak - Viktorýn (2012) also from "the horizon with Spinibole olgae" (cu II $\gamma$-cu II $\delta$, approximately Lower to Middle Viséan) from the vicinity of the village of Březina. Spinibole (C.) coddonensis occurs in south-west England (North Devon) and in Germany (Rhenish Massif: Bergisches Land) (both Early Viséan, approximately cu II $\gamma$ or Late Chadian). Wagnerispina wagneri was described from northern Spain (Late Mississippian: Serpukhovian: Early Namurian, $\mathrm{E}_{1-2}$; Cantabrian Mountains).

\section{Discussion and interpretations}

All the previously described trilobites from the Březina Formation in the valley of the Ríčka Brook (Chlupáč 1966) were obtained from deep boreholes [bore Ochoz (Řícky) 2, bore V 97] situated approximately $100 \mathrm{~m}$ north of the bathing place. Rather poor trilobite material, composed of Liobole aff. glabroides (Richter - Richter, 1949) and "Cyrtosymbole (Macrobole) sp.", was interpreted by Chlupáč (1966) as belonging to the Lower Viséan (cu II $\gamma$ ). 


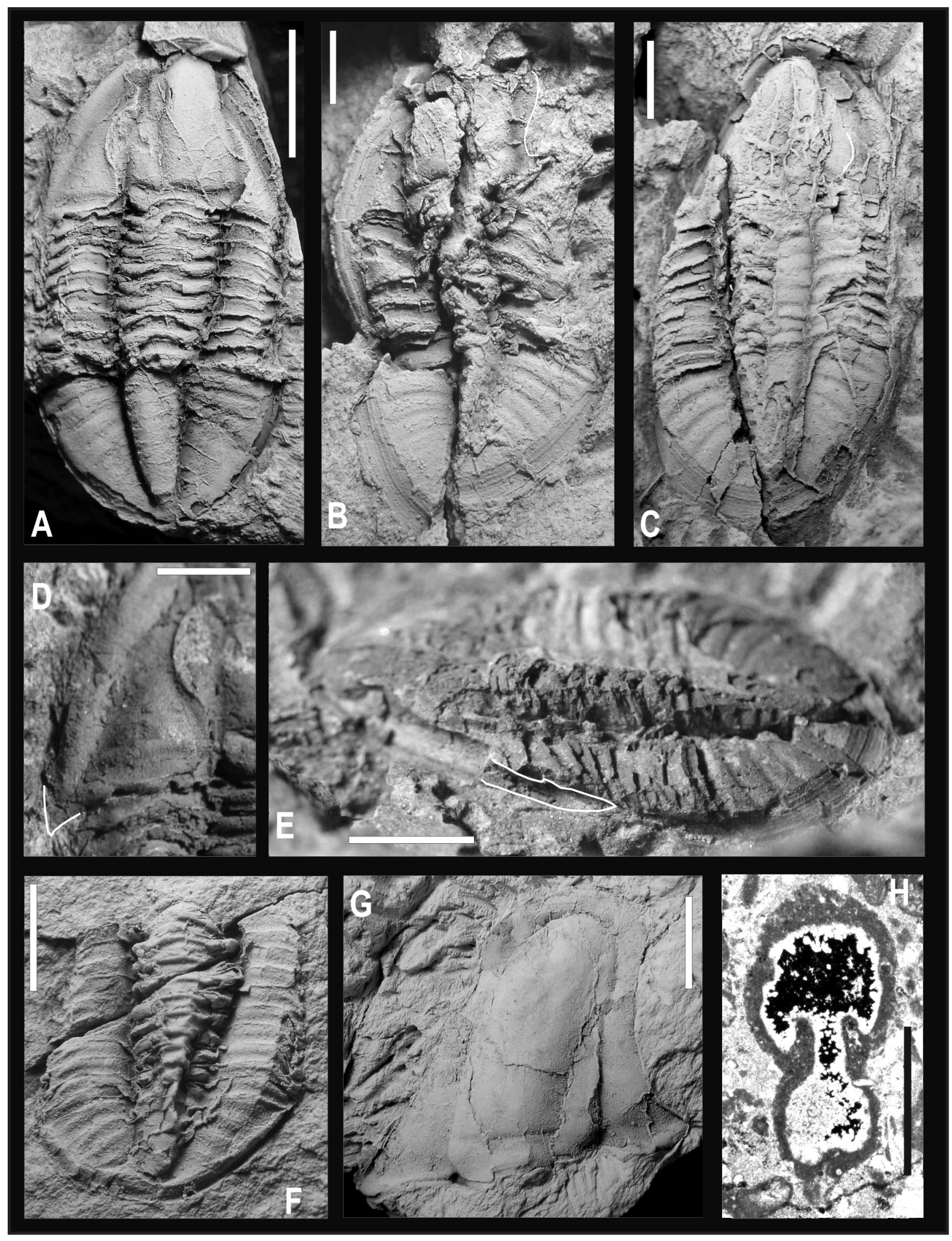

Fig. 2: A - Archegonus (Phillibole) cf. polleni (Woodward, 1894); dorsal view of complete specimen; TW1a. B - Archegonus (Phillibole) cf. cauliquercus Brauckmann, 1981; dorsal view of nearly complete but disarticulated specimen; idealized shape of facial suture marked by white line; TW2. C - Archegonus (Phillibole) cf. cauliquercus Brauckmann, 1981; dorsal view of complete specimen with damaged genal spines; slightly displaced palpebral lobe marked by white line; TW2. D - Archegonus (Phillibole) cf. polleni (Woodward, 1894); dorsolateral view of left librigena of the specimen depicted in A; TW1. E - Archegonus (Phillibole) cf. cauliquercus Brauckmann, 1981; dorsolateral view of the specimen depicted in fig. 2C; mould of fragmentary genal spine marked by white line; TW2. F - ?Spinibole sp.; thoracopygon; TW4. G - Liobole (Liobole) glabra proxima Chlupáč, 1966; lateral view of cranidium; TW3. H - Darjella monilis Malakhova, 1964; specimen from a limestone cobble; thin-section. Scale bars: A, G - 5 mm; B, C, D, E - 2 mm; F- 3 mm; H - $1 \mathrm{~mm}$. Specimens A, B, C, F, G coated by ammonium chloride. All trilobites are housed in the Czech Geological Survey, Prague (inventory numbers TW1-TW4). Photo by T. Weiner, J. Kalvoda. 
Apart from these findings from boreholes, all the previously described Viséan trilobites known from the Březina Formation derive from Březina, Zbrašov near Hranice and Čelechovice. These localities are characterized by occurrence of Spinibole (Spinibole) olgae Chlupáč, 1966, which is accompanied by further taxa ("horizon with Spinibole olgae" sensu Chlupáč 1969). Although about 80 trilobite remnants were collected from the newly discovered fossiliferous beds, none of them belong to Spinibole (S.) olgae. This suggests an absence or infrequent occurrence of this species, which may have very restricted stratigraphical and/or palaeoecologically limited occurrence.

The exact stratigraphic range of Spinibole (S.) olgae is essentially not yet known. Chlupáč $(1966,1969)$ has allocated this species to the Lower Viséan (cu II $\gamma$ ). Owens - Tilsley (1995) have correlated "the horizon with S. olgae" with the Late Chadian assemblage (Lower Viséan, cu II $\gamma$ ) in North Devon. Müller - Brauckmann (2010) have dated their Archegonus (Phillibole) nehdenensis subgroup (= "nehdenensis-Untergruppe") to approximately the cu II $\delta$ (=lower part of Beyrichoceras-Entogonites genozone sensu Korn in Amler - Gereke 2003). All the previously described Moravian specimens from this subgroup are from "the horizon with S. olgae."

The preliminarily studied material from the valley of the Ríćka Brook suggests an age of an extremely long time interval from the Early to Late Viséan (approximately cu II $\gamma$ to $c u$ III $\alpha$ ) and thus from the upper part of the Fascipericyclus-Ammonellipsites to the lower part of the Eoglyphioceras genozones (see Korn - Kaufmann 2008: fig. 7). The Březina Formation is stratigraphically older, however, then cu IIIa (Go III a) because this zone is documented within the lower part of the Myslejovice Formation (see fig. 1D) (Kumpera - Lang 1975, Lehotský 2008). A poorly known stratigraphy of the Rozstání Formation (approximately cu II $\delta$-cu III $\alpha$; fig. 1D), which lies between the Březina and the Myslejovice Formations, was documented by indirect biostratigraphic evidence only (Kalvoda - Bábek 1995). Therefore, the exact age of the newly discovered fossiliferous beds can be approximately allocated to $\mathrm{cu}$ II $\gamma$-cu II $\delta$ (approximately Lower to ?Upper Viséan). "The horizon with S. olgae" seems to correlate with the same interval (cu II $\gamma-\mathrm{cu}$ II $\delta$ ). However, exact stratigraphic relations between associations of "the horizon with S. olgae" and the newly discovered association cannot be unequivocally interpreted.

The assemblage of "the horizon with S. olgae" resembles the Late Chadian atheloptic assemblage known from southwest England (North Devon; Owens - Tilsley 1995). Species with reduced eyes [Liobole (Liobole) glabra proxima, ?Spinibole sp.] co-occur with rather large-eyed species [Archegonus (Ph.) cf. polleni, Archegonus (Ph.) cf. cauliquercus] in the newly discovered fossiliferous beds.

The presence of limestone pebbles and limestone cobbles is not particularly typical for aleuropelitic shales of the Brrezina Formation. Several subangular to rounded pebbles and one subangular limestone cobble were found on the newly discovered locality. The Late Tournaisian foraminifer Darjella monilis Malakhova, 1964 was determined in thin-sections obtained from the limestone cobble (fig. $2 \mathrm{H}$ ). This species ranges from the lower part of the MFZ 7 zone to the MFZ 8 zone sensu Devyust - Hance (in Poty et al. 2006). This cobble is apparently derived from the Hády-Ř́čka Limestones of the Líšeň Formation. The limestone pebbles in all probability also come from the Lišeň Formation (Frasnian-Viséan).

\section{Conclusion}

The trilobite association from the newly discovered fossiliferous parts of the Březina Formation apparently belongs to the Viséan (Lower to ?Upper Viséan). This is in accordance with the occurrence of the reworked Upper Tournaisian limestone cobble. The association seems to be considerably different from other Viséan trilobite associations of the Brezina Formation, which is chiefly demonstrated by the absence (or very rare occurrence) of Spinibole (S.) olgae, co-occurrence of somewhat large-eyed and rather small-eyed trilobites and by the presence of taxa which were previously unknown from the Březina Formation. The new material needs more detailed subsequent study which would follow.

\section{Acknowledgements}

Tomáš Viktorýn is thanked for providing the trilobites of his collections and suggestions of the referee Petr Budil helped to improve the text. The study was supported by the grant project GACR 205/08/0182. 


\section{References}

Amler, M. - Gereke, M. (2003): Karbon-Korrelationstabelle (KKT) Carboniferous Correlation Table (CCT). - Senckenbergiana lethaea, 83, 1/2, 235-247.

Archinal, A. (1992): Revision der Gattung Archegonus (Phillibole) (Trilobita, Ober-Devon/ Unter-Karbon). - Courier Forschungsinstitut Senckenberg, 144, 1-133.

Brauckmann, C. (1981): Eine neue Trilobiten-Art aus dem Kulm (Unter-Karbon cu IIIa) von Aprath (Wuppertal, W-Deutschland). - Jahresberichte des naturwissenschaftlichen Vereins in Wuppertal, 34, 92-95.

Brauckmann, C. (1992): Trilobiten aus dem Ober-Devon und Unter-Karbon im Raum Aprath. - In: Thomas, E. (ed.): Oberdevon und Unterkarbon von Aprath im Bergischen Land (Nördliches Rheinisches Schiefergebirge), 113-167.

Chlupáč, I. (1956): Nález spodnokarbonské fauny u Hranic na Moravě. - Věstník Ústředního ústavu geologického, 31, 268-273.

Chlupáč, I. (1958): Nová spodnokarbonská fauna od Zbrašova u Hranic na Moravě. - Sborník Ústředního ústavu geologického, $24,279-312$.

Chlupáč, I. (1966): The Upper Devonian and Lower Carboniferous trilobites of the Moravian Karst. - Sborník geologických věd, Paleontologie, 7, 1-143.

Chlupáč, I. (1969): Lower Carboniferous fauna from Čelechovice (Moravia) and its significance. - Časopis pro mineralogii a geologii, 2, 211-218.

Gandl, J. (1977): Die Karbon-Trilobiten des Kantabrischen Gebirges (NW-Spanien), 2: Die Trilobiten der Alba-Schichten (Unter-Visé bis Namur A). - Senckenbergiana lethaea, 58, 1/3, 113-217.

Hahn, G. - Hahn, R. (1969): Kulm-Trilobiten von Nehden und Rüthen (Sauerland). - Senckenbergiana lethaea, 50, 4, $273-289$.

Kalvoda, J. - Bábek, O. (1995): Příspěvek k poznání spodní části rozstáňského souvrství (Drahanská vrchovina, Morava). Geologické výzkumy na Moravě a ve Slezsku, 1994, 50-51.

Kalvoda, J. - Devyust, F. X. - Bábek, O. - Dvořák, L. - Rak, Š. - Rez, J. (2010): High-resolution biostratigraphy of the Tournaisian-Visean (Carboniferous) boundary interval, Mokrá quarry, Czech Republic. - Geobios: Paleontology, Stratigraphy, Paleoecology, 43, 317-331.

Korn, D. - Kaufmann, B. (2009): A high-resolution relative time scale for the Visean Stage (Carboniferous) of the Kulm Basin (Rhenish Mountains, Germany). - Geological Journal, 44, 306-321.

Kumpera, O. - Lang, V. (1975): Goniatitová fauna v kulmu Drahanské vysočiny (moravskoslezská zóna Českého masivu). - Časopis Slezského muzea A, 24, 11-32.

Lehotský, T. (2008): Taxonomie goniatitové fauny, biostratigrafie a paleoekologie jesenického a drahanského kulmu. - Disertační práce, Př́rodovědecká fakulta Masarykovy univerzity, 1-131, Brno.

Müller, P. - Brauckmann, C. (2010): Trilobiten-Funde aus dem Unter-Karbon im Hut-Tal (Ober-Harz, Deutschland). - Geologica et Palaeontologica, 43, 83-91.

Owens, R. M. - Tilsley, J. W. (1995): An atheloptic trilobite assemblage from the Carboniferous of North Devon. - Geological Magazine, 132, 6, 713-728.

Poty, E. - Devyust, F. X. - Hance, L. (2006): Upper Devonian and Mississippian foraminiferal and rugose coral zonations of Belgium and Northern France: a tool for Eurasian correlations. - Geological Magazine, 143, 6, 829-857.

Prentice, J. E. (1967): Lower Carboniferous trilobites of North Devon and related species from Northern England. - Bulletin of the British museum (Natural History), Geology, 14, 6, 207-241.

Rak, Š. (2004): Trilobitová fauna hraničních vrstev tournai-visé z Mokré u Brna. - MS, Diplomová práce, Př́rodovědecká fakulta Masarykovy univerzity, 1-67, Brno.

Rak, Š. - Lerosey-Aubril, R. (2009): First record of the Carboniferous trilobite Bollandia from the Moravian Karst (Czech Republic) and its significance. - Bulletin of Geosciences 84, 4, 739-744.

Rak, Š. - Kalvoda, J. - Devuyst, F.-X. (2012): New Mississippian trilobite association from the Brno vicinity and its significance (Moravian Karst, Czech Republic). - Geologica Carpathica, June 2012, 63, 3, 181-190.

Rak, Š. - Viktorýn, T. (2010): Nový nález artikulovaného exoskeletonu trilobita Spinibole (Spinibole) olgae Chlupáč, 1966 z Moravského krasu. - Zprávy o geologickych výzkumech v roce 2009, 31, 268-273.

Rak, Š. - Viktorýn, T. (2012): Předběžné paleontologické zhodnocení lokality Březina 3 a její srovnání s ostatními výskyty trilobitové fauny v břidlicích březinského souvrství v okolí obce Březina v Moravském krasu. - MS, Moravskoslezské paleozoikum 2012, 40-42, Olomouc.

Woodward, H. (1894): Note on a collection of Carboniferous trilobites from the banks of the Hodder, near Stonyhurst, Lancashire. - Geological Magazine 1, 481-489. 